\title{
The effect of pre-procedure anxiety on sedative requirements for sedation during upper gastrointestinal endoscopy
}

\author{
Mehmet Sargın ${ }^{1}$ (D), Mehmet Uluer²(iD) \\ ${ }^{1}$ Department of Anesthesiology and Reanimation, Selçuk University Faculty of Medicine, Konya, Turkey \\ ${ }^{2}$ Clinic of Anesthesiology and Reanimation, Konya Training and Research Hospital, Konya, Turkey
}

\begin{abstract}
Objective: Sedation for upper gastrointestinal endoscopy, commonly used for diagnosis and treatment of gastrointestinal diseases, has been increasing widespread. Sedative agent requirements during sedation or anesthesia can be affected by many factors such as age and sex. In the present study, we aimed to evaluate the effects of pre-procedural anxiety levels on sedative requirements during upper gastrointestinal endoscopy.

Material and Methods: 300 patients between the ages of 18-70 years were studied. Baseline anxiety levels were measured before the procedure using Spielberger's State-Trait Anxiety Inventory (STAI) form X1. Propofol was administered to have BIS values between 65-85 during sedation. Doses of propofol, total procedure time, satisfaction of the patients and endoscopists and BIS values were recorded.

Results: Pre-procedural anxiety was 44 (40-48 [20-70]). We found significant correlations between pre-procedure anxiety and the usage of propofol (mg, $\mathrm{mg} / \mathrm{kg}, \mathrm{mg} / \mathrm{kg} / \mathrm{dk})$ at BIS values between 65-85, [respectively, $(p=0.451, p<0.001),(p=0.455, p<0.001),(p=0.428, p<0.001)$ ]. No correlation was found between pre-procedure anxiety and procedural or sedation complications (respectively $p=0.111, p=0.424$ and $p=0.408, p=0.363$ ). We found significant negative correlations between pre-procedure anxiety and the satisfaction of the patients/endoscopist [respectively, $(p=-0.477, p<0.001),(p=-0.495, p<$ 0.001)].
\end{abstract}

Conclusion: Based on the results of this study, we suggest that there is a significant association between the pre-procedural anxiety levels and use of sedative drugs in patients undergoing upper gastrointestinal endoscopy.

Keywords: Sedation, anxiety, upper gastrointestinal endoscopy

Cite this article as: Sargın M, Uluer M. The effect of preprocedure anxiety on sedative requirements for sedation during upper gastrointestinal endoscopy. Turk J Surg 2020; 36 (4): 368-373.

Corresponding Author

Mehmet Sargın

E-mail: mehmet21sargin@yahoo.com

Received: 10.06 .2020

Accepted: 27.08 .2020

Available Online Date: 29.12.2020

OCopyright 2020 by Turkish Surgical Society Available online at www.turkjsurg.com

DOI: $10.47717 /$ turkjsurg.2020.4532

\section{INTRODUCTION}

Upper gastrointestinal (Gl) endoscopy is commonly used in the diagnosis and treatment of upper Gl disorders. Although the technique is considered to be safe and well tolerated, it is associated with significant patient discomfort and intolerance if sedation is not performed.

Although sedation performed during upper Gl endoscopy increases the costs of the procedure, it is obvious that sedation increases the success rate and makes this procedure more tolerable $(1,2)$. Sedation does not only increase patient satisfaction and tolerance to the procedure, but also makes the patient more persuadable for a repeat procedure (3). Despite this, upper Gl endoscopy is still accepted as an invasive procedure with the potential for discomfort, embarrassment, and disappointment related to unexpected findings. As a result, the presence of anxiety in these patients is not surprising. However, the relationship between the severity of anxiety and individual characteristics of the patients remains unclear. Patient characteristics such as age and sex are suggested to influence the level of anxiety $(4,5)$. It is also likely that the level of anxiety affects both the patient and the endoscopists before and after the procedure, as well as the anesthesiologists who deliver sedation. Previous studies have evaluated the relationship between the level of anxiety and the requirement for sedative or anesthetic agents in patients undergoing sedation or anesthesia; however, there is no consensus on this subject (6-9). 
The present study aimed to evaluate the relationship between the level of pre-procedural anxiety in patients undergoing upper Gl endoscopy and the requirement of sedative agents, patient satisfaction, and complications.

\section{MATERIAL and METHODS}

After obtaining institutional ethics committee approval, informed written consent was obtained from all patients. It has been registered with the Australian New Zealand Clinical Trial Registry (ACTRN12615000369527). Three hundred patients, between the ages of 18-70 years with an ASA physical status I and II, scheduled to undergo planned upper Gl endoscopy were studied. Patients with a history of any upper Gl surgery, a history of a psychiatric disease, insufficient gastric preparation, a predicted difficult airway or allergy to propofol were excluded from the present study. In addition, non-elective patients were excluded from the study. Fasting periods were in accordance with ASA guidelines. All patients were instructed to upper Gl endoscopy preparation is applied as a standard in the endoscopy unit.

Baseline anxiety levels were measured before the procedure while patients waited in the reception area. Each patient was asked to complete Spielberger's State-Trait Anxiety Inventory (STAI) form X (10). STAI measures both state and trait anxiety. STAI-X is subdivided into two different scales, STAI-X1 and -X2, used to evaluate state anxiety and trait anxiety, respectively. STAI-X1 (State Anxiety) contains 20 items based on a 4-point Likert scale and asks the respondent how they feel "right now". The total score may range from 20 to 80, with higher scores representing more severe anxiety (11). STAI has no established categories, but a cutoff score of 40 has been used to identify patients with high/very high anxiety. The validity and reliability of the Turkish versions of these instruments have been conducted $(12,13)$. Immediately after the admission into the reception area, the patients were asked to fill out the STAI-X1 questionnaire. Data were collected by an anaesthetist (MSU) who was blind to the sedation procedures.

A 20-gauge IV catheter was inserted in the right forearm before the patient arrived in the operating room. $0.9 \%$ saline infusion was used to keep the IV line open. BIS monitoring (BIS Monitor, Aspect 2000TM XP, USA) was applied to all patients in addition to routine monitoring (consisting of a pulse oximeter, 3-lead ECG and a non-invasive blood pressure cuff). After baseline measurements (haemodynamic profiles and BIS values) were obtained, the patient was placed in the left lateral position. Supplemental oxygen (4 I.min-1) was administered through a nasal cannula. One milligram of midazolam was administered intravenously. Next, an initial intravenous dose of propofol $(0.3-0.5 \mathrm{mg} / \mathrm{kg}$ of body weight) was administered, followed by repeated 10-20 mg doses so as to BIS values 65-85 or the patient expressed discomfort. Other medications, including analgesics, were not used in the present study. All sedation procedures were practiced by an anaesthetist (MS) who was blind to pre-procedure anxiety scores. If there were any symptoms of respiratory depression or airway obstruction, a simple jaw thrust or chin lift maneuvers was performed.

All endoscopies, also blinded to the anxiety scores, were performed by one of the three endoscopists, each of whom had performed more than 300 endoscopies before participating in the study. Endoscopist satisfaction were evaluated immediately after procedure using a $10-\mathrm{cm}$ visual analog scale. Patient satisfaction was measured using a $10-\mathrm{cm}$ visual analog scale in patients with a modified Aldrete score higher than or equal to 9.

Doses of propofol, total procedure time, satisfaction of patients and endoscopists and BIS values (Basal, after initial dose of propofol, at the second minute of the procedure, at the end of procedure) were recorded. Complications associated with the procedure (Abdominal distension, abdominal pain, nausea and vomiting) were also analyzed. We also recorded any complications associated with sedation (i.e. oxygen saturation $<90 \%$, blood pressure $<90 / 50 \mathrm{~mm} \mathrm{Hg}$, heart rate $<50$ bpm).

\section{Statistical Analysis}

The main association that we examined was between the usage of propofol at BIS values between 65-85 and pre-procedure anxiety. Based on our prior study's (with 50 patients) data, we presumed a correlation coefficient of 0.19 . We needed at least 283 patients to set a significance level of 0.05 (two-sided) and achieve a power of 0.90 . To compensate for possible dropouts, we enrolled 300 patients.

Statistical analyses were performed with SPSS 15.0 software (SPSS Institute, Chicago, IL, USA). The association between the usage of propofol at BIS values between 65-85 and pre-procedure anxiety was assessed by Spearman correlation coefficient. Categorical variables were analyzed using the chi-square test and were given as numbers. A P-value less than 0.05 was considered statistically significant.

\section{RESULTS}

All patients successfully completed STAI-X1. Patients' demographics, basal anxiety scores and hemodynamic profiles are summarized in Table 1. Pre-procedural anxiety was 44 (40-48 [20-70]). The duration of procedure was 4 (3-5 [3-7]) min.

Sedation results (BIS values and propofol doses) for 300 patients are summarized in Table 2. Propofol doses of the 300 patients were 70 (60-80 [20-150]) mg, $1.00(0.75-1.29$ [0.25-2.44]) mg/kg and $0.24(0.16-0.33[0.04-0.81]) \mathrm{mg} / \mathrm{kg} / \mathrm{min}$.

We found significant correlations between pre-procedure anxiety and the usage of propofol (mg) at BIS values between 65-85, $p=0.451$ and $p<0.001$ (Figure 1a). We found significant correlations between pre-procedure anxiety and the usage of propofol (mg/kg) at BIS values between 65-85, $p=0.455$ and $p<0.001$ 
Table 1. Patients' demographics, basal anxiety scores and haemodynamic profiles for 300 patients. Values are as median (IQR[range]), number or number (proportion)

\begin{tabular}{|l|l|}
\hline Age (year) & $40[28-52(18-70)]$ \\
\hline Gender (Male:Female) & $201(67 \%): 99(33 \%)$ \\
\hline Height (cm) & $165[160-170(142-195)]$ \\
\hline Weight (cm) & $70[60-80(40-102)]$ \\
\hline Body mass index (kg/m²) & $25.6[22.0-28.7(15.4-39.5)]$ \\
\hline ASA physical status (I/II) & $200(66.7 \%): 100(33.3 \%)$ \\
\hline Pre-procedurel anxiety & $44[40-48(20-70)]$ \\
\hline Basal HR (beats/min) & $87[78-96(55-119)]$ \\
\hline Basal SBP (mmHg) & $120[111-130(92-149)]$ \\
\hline Basal DBP (mmHg) & $69[60-74(45-97)]$ \\
\hline Basal MBP (mmHg) & $84[77-91(59-112)]$ \\
\hline Duration of procedure (min) & $4[3-5(3-7)]$ \\
\hline $\begin{array}{l}\text { HR:Heart rate, SBP: Systolic blood pressure, DBP: Diastolic blood pressure, MBP: } \\
\text { Mean blood pressure. }\end{array}$ \\
\hline
\end{tabular}

Table 2. Sedation results (BIS values and propofol doses). Values are median (IQR [range])

\begin{tabular}{|l|l|}
\hline BIS-basal & $96[94-97(92-99)]$ \\
\hline BIS-beginning of procedure & $69[66-72(61-78)]$ \\
\hline BIS-at the second min of procedure & $72[70-75(67-80)]$ \\
\hline BIS-end of procedure & $76[75-79(70-85)]$ \\
\hline Propofol doses & \\
\hline $\mathrm{mg} / \mathrm{kg}$ & $1.00[0.75-1.29(0.25-2.44)]$ \\
\hline $\mathrm{mg} / \mathrm{kg} / \mathrm{dk}$ & $0.24[0.16-0.33(0.04-0.81)]$ \\
\hline $\mathrm{mg}$ (total dose) & $70[60-80(20-150)]$ \\
\hline
\end{tabular}

(Figure 1b). We found significant correlations between pre-procedure anxiety and the usage of propofol (mg) at BIS values between 65-85, $p=0.428$ and $p<0.001$ (Figure 1c).

Procedural, sedation complications and satisfaction of the patients and endoscopists are summarized in Table 3. While procedural complications occurred in 54 (18\%) patients, sedation complications occurred in only 7 (2.3\%) patients. No correlation was found between pre-procedure anxiety and the procedural or sedation complications (respectively $p=0.111, p=0.424$ and $p=0.408, p=0.363$ ). Pre-procedure anxiety and satisfaction of the patients are shown in Figure 2a. We found significant negative correlations between pre-procedure anxiety and satisfaction of the patients, $p=-0.477$ and $p<0.001$. Pre-procedure anxiety and satisfaction of the endoscopist are shown in Figure $2 b$. We found significant negative correlations between pre-procedure anxiety and satisfaction of thr endoscopist, $p=-0.495$ and $p<0.001$. During the study period, no patient required assisted ventilation or intubation.
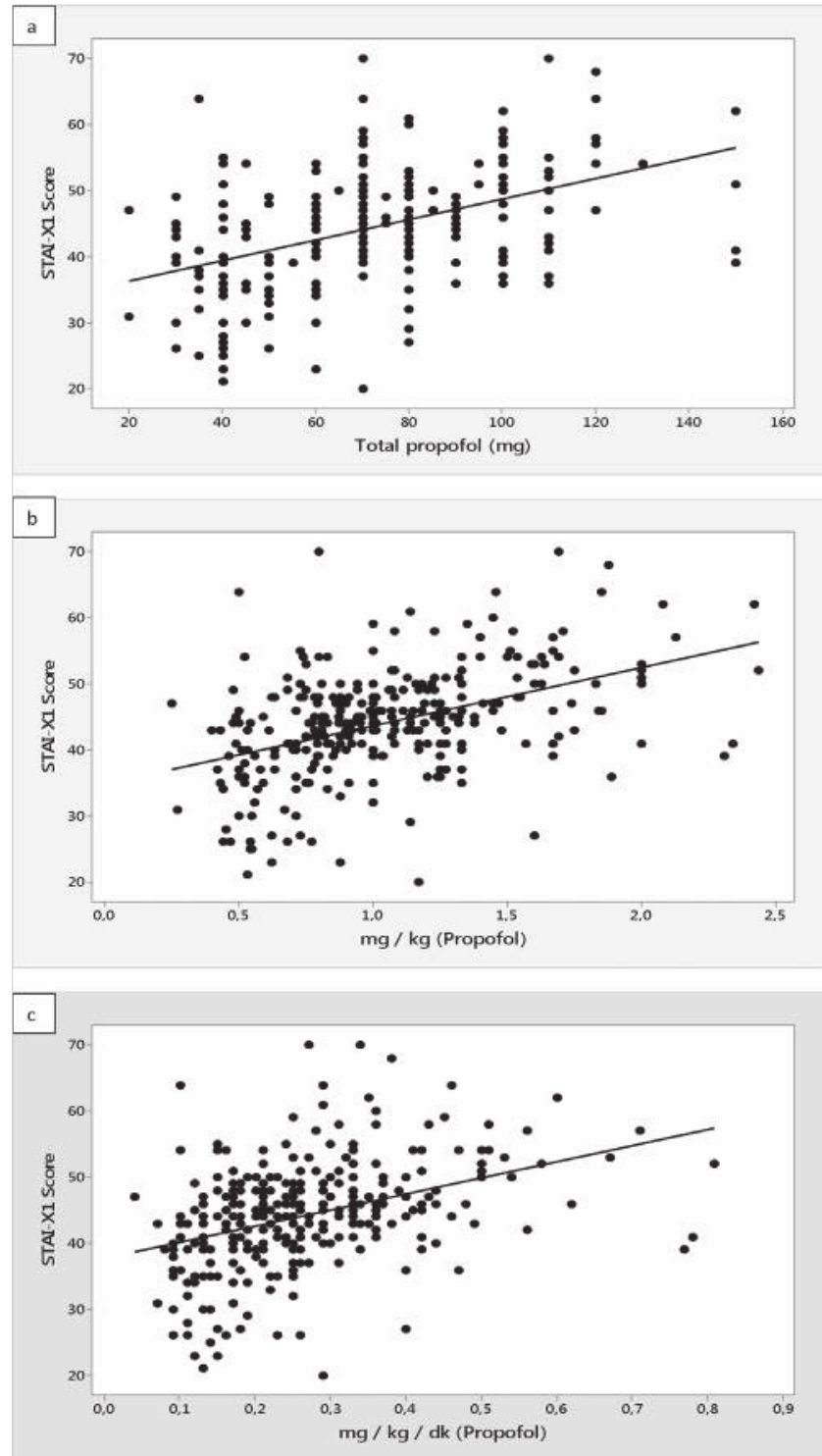

Figure 1. A. Spearman's correlation coefficient between pre-procedure anxiety and the usage of propofol (mg) at BIS values between 65-85. B. Spearman's correlation coefficient between pre-procedure anxiety and the usage of propofol $(\mathrm{mg} / \mathrm{kg}$ ) at BIS values between 65-85. C. Spearman's correlation coefficient between pre-procedure anxiety and the usage of propofol ( $\mathrm{mg} / \mathrm{kg} / \mathrm{min}$ ) at BIS values between 65-85.

\section{DISCUSSION}

The findings of the present study suggest a relationship between a high level of pre-procedural anxiety and an increased propofol requirement for sedation during upper Gl endoscopy. In addition, a negative correlation was suggested between a high level of pro-procedural anxiety in patients undergoing upper Gl endoscopy and the satisfaction of both the patient and the endoscopist. 
Table 3. Complications and satisfaction of patients and endoscopists. Values are number (proportion) or median (IQR [range])

\begin{tabular}{|c|c|}
\hline $\begin{array}{l}\text { Procedural complications } \\
\text { Abdominal distension } \\
\text { Abdominal pain } \\
\text { Nausea and vomiting }\end{array}$ & $\begin{array}{l}54(18 \%) \\
33(11 \%) \\
20(6.7 \%) \\
1(0.3 \%)\end{array}$ \\
\hline $\begin{array}{l}\text { Sedation complications } \\
\text { Blood pressure }<90 / 50 \mathrm{mmHg} \\
\text { Heart rate }<50 \mathrm{bpm}\end{array}$ & $\begin{array}{l}6(2 \%) \\
1(0.3 \%)\end{array}$ \\
\hline Satisfaction of patients & $8[8-10(5-10)]$ \\
\hline Satisfaction of endoscopist & $9[9-10(5-10)]$ \\
\hline mg (total dose) & $70[60-80(20-150)]$ \\
\hline
\end{tabular}

Anxiety is defined as an unpleasant emotional status or circumstance. A state of anxiety is defined as subjective feelings of apprehension, nervousness, worry, and tension when subjected to an anxiety provoking stimulus, whereas trait anxiety is defined as individual differences in the disposition of responses to stressful situations. Various studies have suggested a strong correlation between state and trait anxiety $(8,13,14)$. Previous studies that evaluated the relationship between anxiety and the requirement for anesthetic agent have found different results.

In a study that evaluated the effects of preoperative anxiety on intraoperative anesthetic agent requirements in 57 women that underwent laparoscopic tubal ligation under propofol-based anesthesia reported that state anxiety had no effect on propofol doses, either during the induction or maintenance of anesthesia (7). However, a high level of trait anxiety was shown to be associated with propofol doses both during the induction and maintenance of anesthesia. As in the present study, bispectral index monitoring was used to maintain the hypnotic component of the anesthetic state in that study. Different from this study, however, the present study found a significant correlation between the level of state anxiety and propofol doses. We consider that the difference can be ex- plained by the inclusion of only female patients and the relatively small sample size in the present study.

Another study that evaluated the effects of preoperative anxiety on the requirement for propofol and sevoflurane reported that higher propofol doses were required to achieve light (BIS: 85) and moderate (BIS: 75) levels of sedation in patients that had high anxiety scores (both state and trait) (15). However, the propofol doses required to achieve deeper sedation were only related to the level of trait anxiety.

One study did not report a significant relationship between the level of state and trait anxiety and propofol doses used to induce sedation in 25 patients who underwent extraction of the third molar tooth under intravenous sedation (8). This study also performed BIS to monitor the continuity of sedation. In addition, patients with a high level of anxiety were more predisposed to have unwanted body movements under sedation, and it is obvious that these movements would decrease the satisfaction of the operators.

In a study of patients undergoing sedation for oocyte retrieval, which is another discomforting procedure for the patients, as is upper Gl endoscopy, propofol doses used to achieve sedation were compared between patients with high versus low levels of anxiety, and the doses of propofol were significantly higher in patients with higher levels of anxiety (9). Different from our study, this study used target-controlled infusion (TCI) system, but they did not use BIS to monitor the level of sedation. In addition, they used a simpler scale to assess anxiety levels in their patients as compared to the STAI anxiety scale used in the present study.

The studies mentioned so far are thought to have differences due to their limitations such as small sample size and methodological differences like a lack of BIS monitoring for the depth of sedation $(7-9,14)$.

Using a superior methodological approach compared to these studies, one study that evaluated the effects of pre-procedural

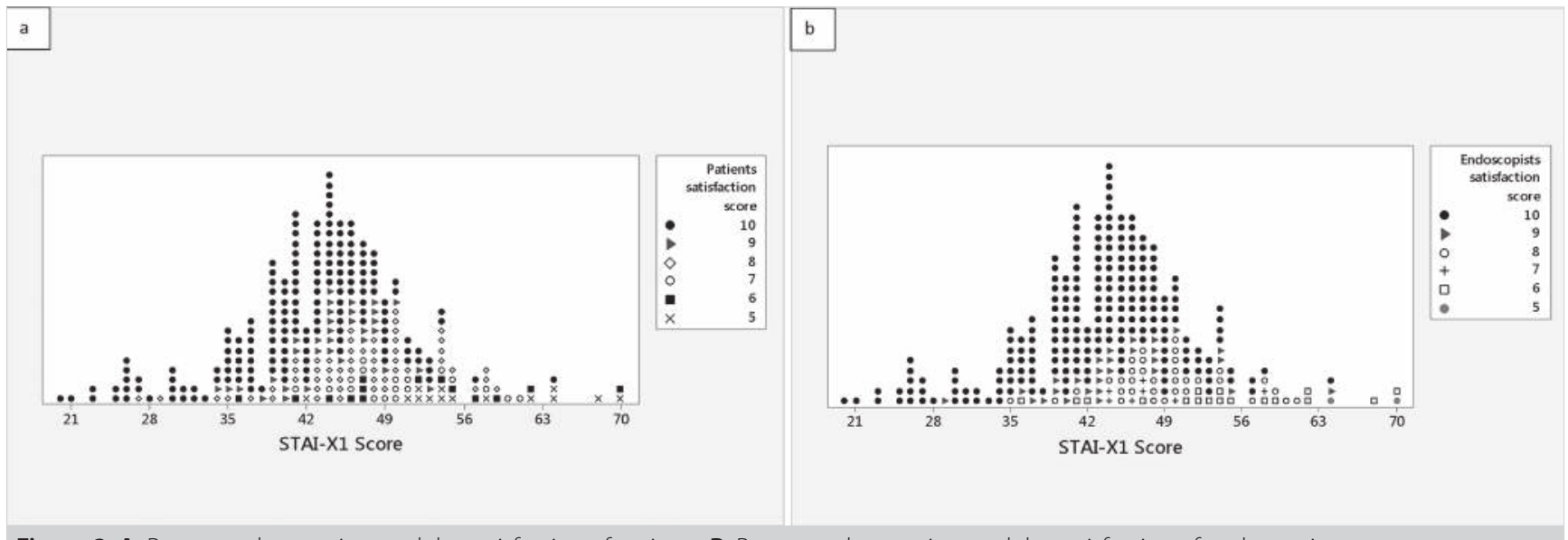

Figure 2. A. Pre-procedure anxiety and the satisfaction of patients. B. Pre-procedure anxiety and the satisfaction of endoscopist. 
anxiety on the use of sedative agents in patients undergoing colonoscopy under sedation reported that pre-procedural anxiety had no effect on sedative agent requirement (6). Similar to our findings, this study did not report a significant correlation between pre-procedural anxiety and procedural complications. However, the present study showed a decrease in patient satisfaction with increasing levels of anxiety, while their study did not report a relationship between the level of anxiety and patient satisfaction. Different from our study, they used the TCI system and not BIS monitoring. In addition, they used an anxiety assessment scale, which is different than that which was used in the present study.

BIS monitoring is used to optimize the depth of sedation at the beginning and maintenance of sedation in the endoscopic procedure, and this method increases patient satisfaction and tolerability of the procedure and also decreases patient awareness during the procedure $(16,17)$. Furthermore, BIS can be a useful monitoring guide for the titration of propofol by physicians who are competent in airway and hemodynamic management (18). Along with these advantages, BIS monitoring during sedation has been shown to reduce propofol doses (19).

\section{Study Limitations}

The present study has some limitations. First, we did not use the $\mathrm{TCl}$ system to monitor propofol use and consumption. Second, BIS scores could have been maintained within a narrower range instead of 65-85 or the patients could have been divided into two groups as 65-75 and 75-80 points. Third, we could have also evaluated trait anxiety and not only state anxiety. However, we do not expect a significant influence on the results due to the fact that previous studies reported a strong correlation between state anxiety and trait anxiety (14-16).

\section{CONCLUSION}

In conclusion, we suggest the presence of a significant relationship between high levels of anxiety and the use of sedative agents in patients undergoing upper Gl endoscopy. For this reason, pre-procedural anxiety levels of the patients must be taken into consideration while using sedative agents to induce sedation during upper Gl endoscopy.

Ethics Committee Approval: The approval for this study was obtained from Necmettin Erbakan University Ethics Committee for Clinical Research with non-Pharmaceutical Products and non-Medical Device (Decision No: 14567952-050/, Date: 28.11.2014)

Peer-review: Externally peer-reviewed.

Author Contributions: Concept - M.S., M.U.; Design - M.S.; Supervision M.S., M.U.; Resource - M.S., M.U.; Materials - M.S., M.U.; Data Collection and/or Processing - M.S., M.U.; Analysis and Interpretation - M.S.; Literature Review - M.S.; Writing Manuscript - M.S., M.U.; Critical Reviews - M.S..

Conflict of Interest: The authors declare that they have no conflict of interest.
Financial Disclosure: The authors declared that this study has received no financial support.

\section{REFERENCES}

1. Ross WA. Premedication for upper gastrointestinal endoscopy. Gastrointest Endosc 1989; 35: 120-6. [CrossRef]

2. Campo R, Brullet E, Montserrat A, Calvet X, Rivero E, Brotons C. Topical pharyngeal anesthesia improves tolerance of upper gastrointestinal endoscopy: a randomized double-blind study. Endoscopy 1995; 27(9): 659-64. [CrossRef]

3. Rex DK, Khalfan HK. Sedation and the technical performance of colonoscopy. Gastrointest Endosc Clin N Am 2005; 15: 661-72. [CrossRef]

4. Ersöz F, Toros AB, Aydoğan G, Bektaş H, Ozcan O, Arikan S. Assessment of anxiety levels in patients during elective upper gastrointestinal endoscopy and colonoscopy. Turk J Gastroenterol 2010; 21(1): 29-33. [CrossRef]

5. Lee SY, Son HJ, Lee JM, Bae MH, Kim JJ, Paik SW, et al. Identification of factors that influence conscious sedation in gastrointestinal endoscopy. J Korean Med Sci 2004; 19(4): 536-40. [CrossRef]

6. Chung KC, Juang SE, Lee KC, Hu WH, Lu CC, Lu HF, et al. The effect of pre-procedure anxiety on sedative requirements for sedation during colonoscopy. Anaesthesia 2013; 68(3): 253-9. [CrossRef]

7. Maranets I, Kain ZN. Preoperative anxiety and intraoperative anesthetic requirements. Anesth Analg 1999; 89(6): 1346-51. [CrossRef]

8. Osborn TM, Sandler NA. The effects of preoperative anxiety on intravenous sedation. Anesth Prog 2004; 51(2): 46-51. [CrossRef]

9. Hong JY, Jee YS, Luthardt FW. Comparison of conscious sedation for oocyte retrieval between low-anxiety and high-anxiety patients. J Clin Anesth 2005; 17(7): 549-53. [CrossRef]

10. de Groot KI, Boeke S, van den Berge HJ, Duivenvoorden HJ, Bonke B, Passchier $\mathrm{J}$. The influence of psychological variables on postoperative anxiety and physical complaints in patients undergoing lumbar surgery. Pain 1997; 69: 19-25. [CrossRef]

11. Bell GD, Reeve PA, Moshiri M, Morden A, Coady T, Stapleton PJ, et al. Intravenous midazolam: a study of the degree of oxygen desaturation occurring during upper gastrointestinal endoscopy. Br J Clin Pharmacol 1987; 23: 703-8. [CrossRef]

12. Iwakiri H, Nishihara N, Nagata O, Matsukawa T, Ozaki M, Sessler DI. Individual effect-site concentrations of propofol are similar at loss of consciousness and at awakening. Anesth Analg 2005; 100: 107-10. [CrossRef]

13. Spielberger CD. Manual for the State-Trait Anxiety Inventory (STAl: Form Y). Palo Alto, CA: Consulting Psychologists Press; 1983. [CrossRef]

14. Bisgaard T, Klarskov B, Rosenberg J, Kehlet H. Characteristics and prediction of early pain after laparoscopic cholecystectomy. Pain 2001; 90: 261-9. [CrossRef]

15. Kil HK, Kim WO, Chung WY, Kim GH, Seo H, Hong JY. Preoperative anxiety and pain sensitivity are independent predictors of propofol and sevoflurane requirements in general anaesthesia. Br J Anaesth 2012; 108(1): 119-25. [CrossRef]

16. Kearse $L A$, Rosow C, Zaslavsky A, Connors P, Dershwitz M, Denman W. Bispectral analysis of the electroencephalogram predicts conscious processing of information during propofol sedation and hypnosis. Anesthesiology 1998; 88: 25-34. [CrossRef] 
17. Leslie K, Sessler DI, Schroeder M, Walters K. Propofol blood concentration and the bispectral index predict suppression of learning during propofol/epidural anesthesia in volunteers. Anesth Analg 1995; 81: 1269-74. [CrossRef]

18. Powers KS, Nazarian EB, Tapyrik SA, Kohli SM, Yin H, van der Jagt EW, et al. Bispectral index as a guide for titration of propofol during procedural sedation among children. Pediatrics 2005; 115(6): 1666-74. [CrossRef]
19. Park WY, Shin YS, Lee SK, Kim SY, Lee TK, Choi YS. Bispectral index monitoring during anesthesiologist-directed propofol and remifentanil sedation for endoscopic submucosal dissection: a prospective randomized controlled trial. Yonsei Med J 2014; 55(5): 1421-9. [CrossRef]

\section{ORIJINAL ÇALIŞMA-ÖZET}

Turk J Surg 2020; 36 (4): 368-373

\section{Pre-prosedürel anksiyetenin üst gastrointestinal endoskopi sırasında uygulanan sedasyonda sedatif ajan gereksinimi üzerine etkisi}

Mehmet Sargın ${ }^{1}$, Mehmet Uluer ${ }^{2}$

${ }^{1}$ Selçuk Üniversitesi Tıp Fakültesi, Anesteziyoloji ve Reanimasyon Anabilim Dalı, Konya, Türkiye

${ }^{2}$ Konya Eğitim ve Araştırma Hastanesi, Anesteziyoloji ve Reanimasyon Kliniği, Konya, Türkiye

\section{ÖZET}

Giriş ve Amaç: Gastrointestinal hastalıkların tanı ve tedavisinde yaygın olarak kullanılan üst gastrointestinal endoskopide sedasyon yaygınlaşmaktadır. Sedasyon veya anestezi sırasında sedatif ajanların gereksinimleri yaş ve cinsiyet gibi birçok faktör tarafından etkilenebilir. Bu çalışmada, üst gastrointestinal endoskopide işlem öncesi anksiyete düzeylerinin sedatif gereksinimlere olan etkilerini değerlendirmeyi amaçladık.

Gereç ve Yöntem: 18-70 yaş arasındaki 300 hasta çalışmaya alındı. Bazal anksiyete düzeyleri, işlem öncesi Spielberger'in Devlet Sürekli Anksiyete Envanteri (STAI) X1 formunu kullanarak ölçülmüştür. Sedasyon sırasında BID değerleri 65-85 arasında tutuldu. Propofol dozları, toplam işlem süresi, hasta ve endoskopist memnuniyeti ve BIS değerleri kaydedildi.

Bulgular: işlem öncesi anksiyete 44 idi (40-48 [20-70]). BIS değerleri 65-85 arasında tutulduğunda, işlem öncesi kaygı ile propofol kullanımı (mg, $\mathrm{mg} / \mathrm{kg}, \mathrm{mg} / \mathrm{kg} / \mathrm{dk})$ arasında anlamlı korelasyon bulduk [Sırasıyla, $(p=0,451, p<0,001),(p=0,455, p<0,001),(p=0,428, p<0,001)]$. Isslem öncesi anksiyete ile işlemsel veya sedasyon komplikasyonları arasında korelasyon saptanmadı (Sırasılla $p=0,111, p=0,424$ ve $p=0,408, p=0,363$ ). Işlem öncesi kaygı ile hasta/endoskopistin memnuniyeti arasında anlamlı negatif korelasyon bulduk, [Sırasıyla, $(p=-0,477, p<0,001),(p=-0,495, p<0,001)]$.

Sonuç: Bu çalışmanın sonuçlarına dayanarak, üst gastrointestinal endoskopi uygulanan hastalarda işlem öncesi anksiyete düzeyleri ile sedatif ajan kullanımı arasında anlamlı bir ilişki olduğunu düşünmekteyiz.

Anahtar Kelimeler: Sedasyon, anksiyete, üst gastrointestinal endoskopi

Doi: $10.47717 /$ turkjsurg.2020.4532 